Вопросы языкознания 2013-2023

ISSN 2079-8784

URL - http: $\underline{\text { /ras }} . j \underline{\text { es.su }}$

Все права защищены

Номер 6 Том . 2018

\title{
M. Norde, F. van de Velde (eds.). Exaptation and language change. Amsterdam: John Benjamins, 2016
}

\section{Гращенков Павел Валерьевич}

МГУ имени М. В. Ломоносова

Институт востоковедения РАН

Государственный институт русского языка им. А. С. Пушкина

Российская Федераџия, Москва

Аннотация

\section{Ключевые слова:}

Дата публикации: 26.11.2018

Источник финансирования:

Работа написана при поддержке проекта РНФ 18-18-00462 «Коммуникативносинтаксический интерфейс: типология и грамматика», реализуемого в Государственном институте русского языка им. А. С. Пушкина.

\section{Ссылка для цитирования:}

Гращенков П. В. М. Norde, F. van de Velde (eds.). Exaptation and language change. Amsterdam: John Benjamins, 2016 // Вопросы языкознания - 2018. - Номер 6 C. 139-147 [Электронный pecypc]. URL: http://ras.jes.su/vopjaz/s207987840001249-2-1 (дата обращения: 26.04.2023). DOI: 10.31857/S0373658X0002025-6

1 [Рец. на: / Review of:] M. Norde, F. van de Velde (eds.). Exaptation and language change. Amsterdam: John Benjamins, 2016. viii, 411 p. ISBN 978-90-2726747-4. 


\section{Библиография:}

1. Кузин 2016 - Кузин И. А. Критика адаптационизма в эволюционной биологии и ее значение для философии науки. Дисс. ... канд. филос. наук. М.: МГУ, 2016.

2. Andersen 2006 - Andersen H. Synchrony, diachrony, and evolution. Competing models of linguistic change: Evolution and beyond. Thomsen O. N. (ed.). (Current Issues in Linguistic Theory, 279.) Amsterdam: John Benjamins, 2006. Pp. 59-90.

3. Croft 2008 - Croft W. Evolutionary linguistics. Annual Review of Anthropology. 2008. Vol. 37. Pp. 219-234.

4. Croft 2013 - Croft W. Evolution: Language use and the evolution of languages. The language phenomenon. Smith K., Binder P. (eds.). Berlin: Springer, 2013. Pp. 93-120.

5. Fitch et al. 2005 - Fitch W. T., Hauser M. D., Chomsky N. The evolution of the language faculty: Clarifications and implications. Cognition. 2005. Vol. 97. No. 2. Pp. $179-210$.

6. Givón 2015 - Givón T. The diachrony of grammar. Amsterdam: John Benjamins, 2015.

7. Gould, Lewontin 1979 - Gould S. J., Lewontin R. C. The spandrels of San Marco and the Panglossian paradigm: A critique of the adaptationist programme. Proceedings of the Royal Society of London. Series B. Biological sciences. 1979. Vol. 205. No. 1161. Pp. 581-598.

8. Gould, Vrba 1982 - Gould S. J., Vrba E. S. Exaptation - A missing term in the science of form. Paleobiology. 1982. Vol. 8. No. 1. Pp. 4-15.

9. Heine 2003 - Heine B. On degrammaticalization. Historical Linguistics 2001: Selected papers from the 15th International Conference on Historical Linguistics, Melbourne, 13-17 August 2001. Blake B. J., Burridge K. (eds.). (Current Issues in Linguistic Theory, 237.) Amsterdam: John Benjamins, 2003. Pp. 163-179.

10. Hopper, Traugott 2003 - Hopper P. J., Traugott E. C. Grammaticalization. 2nd ed. Cambridge: Cambridge Univ. Press, 2003.

11. Jackendoff, Pinker 2005 - Jackendoff R., Pinker S. The nature of the language faculty and its implications for evolution of language (reply to Fitch, Hauser, and Chomsky). Cognition. 2005. Vol. 97. No. 2. Pp. 211-225.

12. Kuryłowicz 1965 - Kuryłowicz J. The evolution of grammatical categories. Diogenes. 1965. Vol. 51. Pp. 55-71.

13. Lass 1990 - Lass R. How to do things with junk: Exaptation in language evolution. Journal of Linguistics. 1990. Vol. 26. Pp. 79-102. 
14. Lightfoot 1979 — Lightfoot D. Principles of diachronic syntax. Cambridge: Cambridge Univ. Press, 1979.

15. Prum, Brush 2014 - Prum R. O., Brush A. H. Which came first, the feather or the bird? Scientific American. 2014. Vol. 23. Pp. 76-85.

16. Roberts 2003 - Roberts I. Diachronic syntax. Oxford: Oxford Univ. Press, 2003.

17. Roberts, Roussou 2003 - Roberts I., Roussou A. Syntactic change. A Minimalist approach to grammaticalization. Cambridge: Cambridge Univ. Press, 2003.

18. Traugott 2004 - Traugott E. C. Exaptation and grammaticalization. Linguistic studies based on corpora. Akimoto M. (ed.). Tokyo: Hituzi Syobo, 2004. Pp. 133-156.

19. Uriagereka 2008 - Uriagereka J. Syntactic anchors: On semantic structuring. Cambridge: Cambridge Univ. Press, 2008.

20. Vincent 1995 - Vincent N. Exaptation and grammaticalization. Historical Linguistics 1993. Andersen H. (ed.). (Current Issues in Linguistic Theory, 124.) Amsterdam: John Benjamins, 1995. Pp. 433-445. 


\section{Norde, F. van de Velde (eds.). Exaptation and language change. Amsterdam: John Benjamins, 2016}

\section{Pavel Grashchenkov}

Lomonosov Moscow State University

Institute of Oriental Studies, Russian Academy of Sciences

Pushkin State Russian Language Institute

Russian Federation, Moscow

Abstract

Keywords:

Publication date: 26.11 .2018

Citation link:

Grashchenkov P. M. Norde, F. van de Velde (eds.). Exaptation and language change. Amsterdam: John Benjamins, 2016 // Voprosy Jazykoznanija - 2018. - Issue 6 C. 139147 [Electronic resource]. URL: http://ras.jes.su/vopjaz/s207987840001249-2-1 (circulation date: 26.04.2023). DOI: 10.31857/S0373658X0002025-6 